\title{
Implementasi Teknologi Mikroservice pada Pengembangan Mobile Learning
}

\author{
Maksy Sendiang ${ }^{1 *}$, Sonny Kasenda ${ }^{2 * *}$, Jerry Purnama ${ }^{3 *}$ \\ * Teknik Informatika, Politeknik Negeri Manado \\ ** Teknik Listrik, Politeknik Negeri Manado \\ *** Teknik Mesin, Politeknik Negeri Manado \\ $\underline{\text { maksysendiang05@gmail.com }}{ }^{1}, \underline{\text { sonnykasenda@gmail.com }}^{2}$, , jhpurnama67@gmail.com $^{3}$
}

\begin{tabular}{l} 
Article Info \\
\hline Article history: \\
Received : 08-11-2018 \\
Revised : 26-11-2018 \\
Accepted : 05-12-2018 \\
\hline
\end{tabular}

\section{Keyword:}

microservice, mLearning,

entity,

$U M L$,

$R U P$.

\begin{abstract}
Software development using microservice has many advantages over conventional technology. The short number of comprehension and applied examples of microservice technology have caused the software developed using this technology is confined. This research aims to apply microservice technology in the development of mobile learning (MLearning). Implementation of microservice will break the application into stand-alone entities and isolated with others. Thus failure in an entity will not effect the application as a whole system. This research using a mixture of quantitative and qualitative methods in collecting and analyzing data. The data obtained is modeled with an object-oriented approach by used Unified Modelling Language tool (UML). RUP method as one of software development method that gives focus to software architecture is used to develop the MLearning. By this research expected a MLearning is produced using microservice technology. It is expected this MLearning will improve the quality of education in Manado State Vocational High School. The conclusion of this research is that the development of MLearning with microservice technology will form a robust application that gives a positive impact on teaching and learning process at Manado State Vocational High School.
\end{abstract}

\section{Pendahuluan}

Diera teknologi digital saat ini, penggunaan perangkat mobile menjadi kebutuhan baik individu maupun organisasi dalam meningkatkan kinerjanya. Perangkat mobile menjadi alat praktis dalam mengakses informasi maupun berkomunikasi sehingga digunakan dalam berbagai bidang baik pendidikan, kesehatan, sosial dan lain - lain. Pesatnya perkembangan perangkat mobile ditunjang oleh kemajuan inovasi baik dibidang perangkat keras maupun perangkat lunak. Di bidang perangkat lunak, menjamurnya aplikasi - aplikasi mobile seperti eLearning, eGoernment, game telah menambah fungsionalitas perangkat lunak dan berdampak pada permintaan pasar terhadap perangkat mobile terus meningkat dari waktu ke waktu.

Mobile learning (mLearning) adalah aplikasi eLearning yang dijalankan menggunakan perangkat mobile. Cavus
"Mobile learning is defined as using mobile devices such as cell phones, laptops, PCs, PC tablets, PDS and other handheld device in conjunction with wireless internet network to enable multimedia communication using text, voice, video and graphics data. M-Learning allows student to exchange messages, sounds, pictures and other rich communication among themselves using internet" [1]. According to [2] "mobile learning is defined as any sort of learning that happens when the learner is not at a fixed, predetermined location, or learning that happens when the learner takes advantage of the learning opportunities offered by mobile technologies". Mobile learning menyediakan fasilitas pembelajaran tanpa dibatasi oleh tempat dan waktu. Dengan menggunakan mobile learning pelajar dengan berbagai latarbelakang bahkan para penyandang cacat sekalipun dapat memanfaatkan fasilitas pembelajaran jarak jauh. Selain itu mobile learning menyediakan fasilitas yang tidak dapat disediakan oleh 
peralatan lainnya seperti kemampuan pengambilan dan sharing gambar secara real time, peta dan GPS. Dengan integrasi jaringan wireless, peralatan mobile dan teknologi jaringan lainnya, mobile learning menyediakan fasilitas pendidikan dan pembelajaran yang mengesankan [8]

Perangkat lunak dalam skala yang besar umumnya dibangun dengan cara terdistribusi dan terdiri atas berbagai media yang terhubung dalam satu jaringan. Dalam konteks ini, mikroservice adalah sebuah pola pengembangan perangkat lunak yang baru dimana keseluruhan fungsi perangkat lunak disediakan oleh komponen - komponen perangkat lunak yang lebih kecil. Komponen - komponen ini menggunakan dan menyediakan layanan perangkat lunak dan dikembangkan oleh tim secara terpisah. Tidak seperti pengembangan perangkat lunak secara tradisional dimana tim pengembang dan tim operasional terpisah, pada mikroservice masing - masing tim menyediakan semua persyaratan pengembangan dan operasional untuk service atau layanan yang dibangun (DevOPs).

Gambar dibawah ini menunjukkan contoh sistem mikroservice yang terdiri atas lima service (layanan) yang bekerja sama untuk menyediakan aplikasi bagi external user.

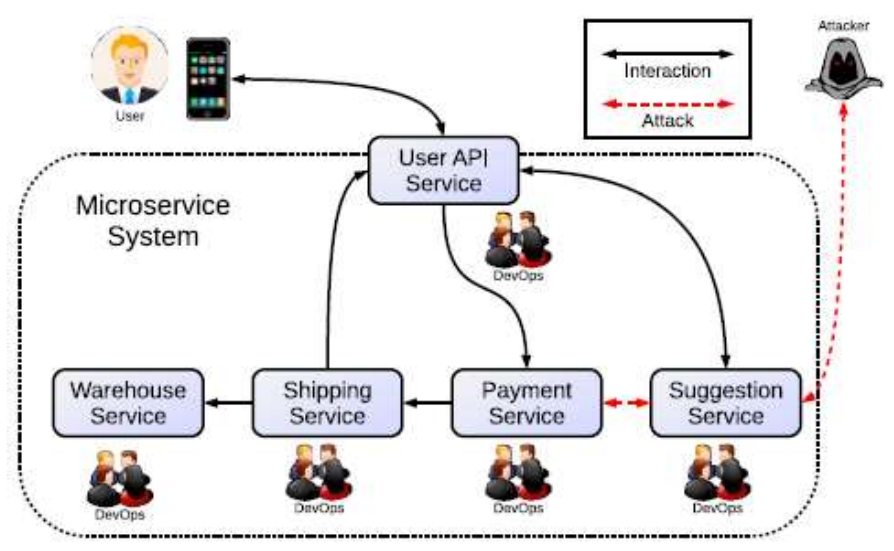

Gambar 1.Sistem Mikroservice

Pengguna menjalankan aplikasi client baik aplikasi mobile maupun aplikasi berbasis web yang mengakses external User API yang disediakan oleh sistem. API service memangil internall service yang menyediakan fungsi yang diminta (warehause service, shipping serice, payment service, suggestion service). Setiap service ini dimaintain oleh DevOps tim yang mengembangkan, mendeploy dan merawat sistem sistem tersebut.

Seperti yang dicantumkan diatas, pengembangan perangkat lunak menggunakan teknologi microservice memiliki banyak kelebihan dibandingkan dengan teknologi konvensional. Kurangnya pemahaman dan contoh terapan tentang teknologi microservice menjadi salah satu penyebab minimnya perangkat lunak yang dikembangkan menggunakan teknologi ini. Penelitan ini bertujuan menerapkan teknologi microservice dalam pengembangan mobile learning (MLearning). Penerapan microservice akan memecah aplikasi kedalam entity - entity yang berdiri sendiri dan terisolasi dengan entity lainnya. Dengan demikian kegagalan disatu entity tidak akan mempengaruhi aplikasi secara keseluruhan

\section{METODE PENELITIAN}

Metode pengembanang sistem yang dipakai dalam pengembangan aplikasi ini adalah Rational Unified Process (RUP). Metode ini digunakan karena waktu yang dibutuhkan dalam pengembangan aplikasi ini tergolong singkat dan juga aplikasi ini akan mengalami perbaikan perbaikan selama proses pengembangannya.

Rational Unified Process (RUP) proses pengembangan perangkat lunak yang paling luas digunakan saat ini oleh team yang terlibat dalam pengembangan perangkat lunak (system analis, project manager) [6].

RUP merupakan proses rekayasa perangkat lunak dengan pendefinisian yang baik dan penstrukturan yang baik. RUP menyediakan pendefinisian struktur yang baik untuk alur hidup proyek perangkat lunak. RUP memiliki empat buah tahapan atau fase yang dapat dilakukan secara iteratif. Dalam metodologi ini ada empat tahap pengembangan perangkat lunak yaitu :

1) Inception (permulaan) adalah tahap memodelkan proses bisnis yang dibutuhkan dan mendefinisikan kebutuhan akan sistem yang akan dibuat.

2) Elaboration (perluasan/perencanaan), lebih difokuskan pada perencanan arsitektur sistem. Tahap ini juga dapat dibuat untuk menentukan apakah arsitektur sistem yang diinginkan dapat dibuat atau tidak. Tahap ini memberikan penekanan pula pada analisis dari desain sistem dan implementasi sistem dan hasil yang diharapkan dari tahap ini adalah memenuhi Lifecycle Architecture Milestone (batas/tonggak arsitektur dari siklus)

3) Construction (Konstruksi), tahap ini lebih fokus pada pengembangan komponen atau fitur-fitur sistem.

4) Transition (Transisi), tahap ini lebih pada deployment atau instalasi sistem agar dapat dimengerti oleh user. Aktivitas pada tahap ini termasuk pada pelatihan user, pemeliharaan, dan pengujian sistem apakah sudah memenuhi harapan user

Sumber data untuk penelitian ini berasal dari enam Sekolah Menengah Kejuruan Negeri yang ada di kota Manado dan Dinas Pendidikan dan Kebudayaan kota Manado. Data didapat melalui wawancara dan pengamatan langsung di lapangan. Data selanjutnya diolah di Laboratorium Pemrograman Jurusan Teknik Elektro Politeknik Negeri Manado. 


\section{HASIL DAN PEMBAHASAN}

\section{A. Pemodelan Sistem}

Model sistem yang dibangun ini dapat dilihat pada diagam UML berikut ini :

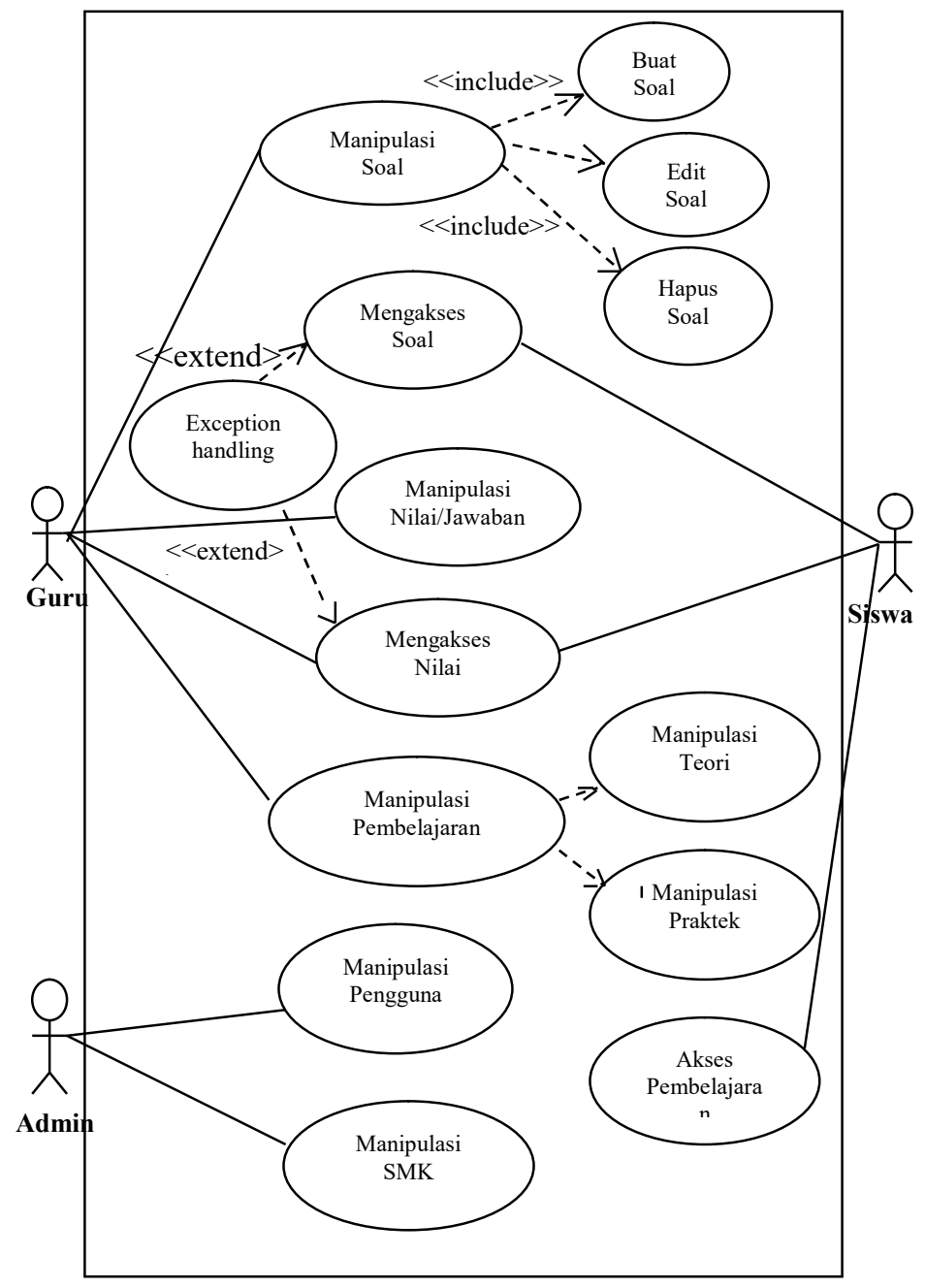

Gambar 2.Use Case Diagram

Sesuai gambar model UML diatas, system yang dibangun penggunanya terdiri atas tiga kategori yaitu admin, guru dan siswa dengan hak aksesnya masing masing. Hak akses ini dikembangkan pada tahap dua (elaboration) dari metode pengembangan system RUP diatas. Hak akses yang digambarkan dalam bentuk use case diuraikan lebih terperinci dalam table 1.

\section{B. Arsitektur Sistem}

Arsitektur sistem yang dibangun ini mengacu pada functional requirement yang diperoleh dari hasil wawancara dengan calon pengguna dan memanfaatkan referensi dari studi pustaka. Functional requirement disusun dalam bentuk tabel (tabel 1) dan terdiri atas aktor requirement dan functional requirement. Aktor adalah user yang akan menggunakan aplikasi yaitu admin, guru dan siswa.

TABEL I

FUNCTIONAL REQUIREMENT

\begin{tabular}{|c|c|c|}
\hline ID & Aktor & Functional Requirement \\
\hline 001 & \multirow{8}{*}{ Guru } & Membuat soal \\
\hline 002 & & Menghapus dan mengedit soal \\
\hline 003 & & Memasukkan nilai \\
\hline 004 & & Mengedit dan menghapus nilai \\
\hline 005 & & Membuat jawaban \\
\hline 006 & & Mengedit dan menghapus jawaban \\
\hline 007 & & $\begin{array}{l}\text { Memasukkan materi pembelajaran } \\
\text { teori dan praktek }\end{array}$ \\
\hline 008 & & $\begin{array}{l}\text { Mengedit dan menghapus materi } \\
\text { pembelajaran }\end{array}$ \\
\hline 009 & \multirow{6}{*}{ Admin } & Memasukaan data SMK \\
\hline 0010 & & $\begin{array}{l}\text { Mengedit dan menghapus data } \\
\text { SMK }\end{array}$ \\
\hline 0011 & & Memasukkan data mata pelajaran \\
\hline 0012 & & $\begin{array}{l}\text { Mengedit dan menghapus data mata } \\
\text { pelajaran }\end{array}$ \\
\hline 0013 & & Memasukkan data pengguna \\
\hline 0014 & & $\begin{array}{l}\text { Mengedit dan menghapus data } \\
\text { pengguna }\end{array}$ \\
\hline 0015 & \multirow{2}{*}{ Siswa } & Mengakses soal \\
\hline 0016 & & Mengakses Nilai \\
\hline
\end{tabular}

Tabel 1 diatas mengacu pada hasil perancangan yang kemudian dimodelkan dengan UML. Guru dalam konteks ini hanya akan melakukan manipulasi materi, soal dan penilaian yang berhubungan dengan mata pelajaran yang diampuhnya. Data - data yang bersifat umum dimasukan dan diperbarui oleh admin. Sementara siswa hanya memiliki akses terhadap soal dan hasil penilaian.

Aristektur sistem mikroservice yang dibangun ini adalah seperti pada gambar 3. Untuk implementasi arsitektur mikroservice menggunakan framework lumen. Lumen adalah bagian dari framework laravel yang dipergunakan untuk mengembangkan mikroservice. 


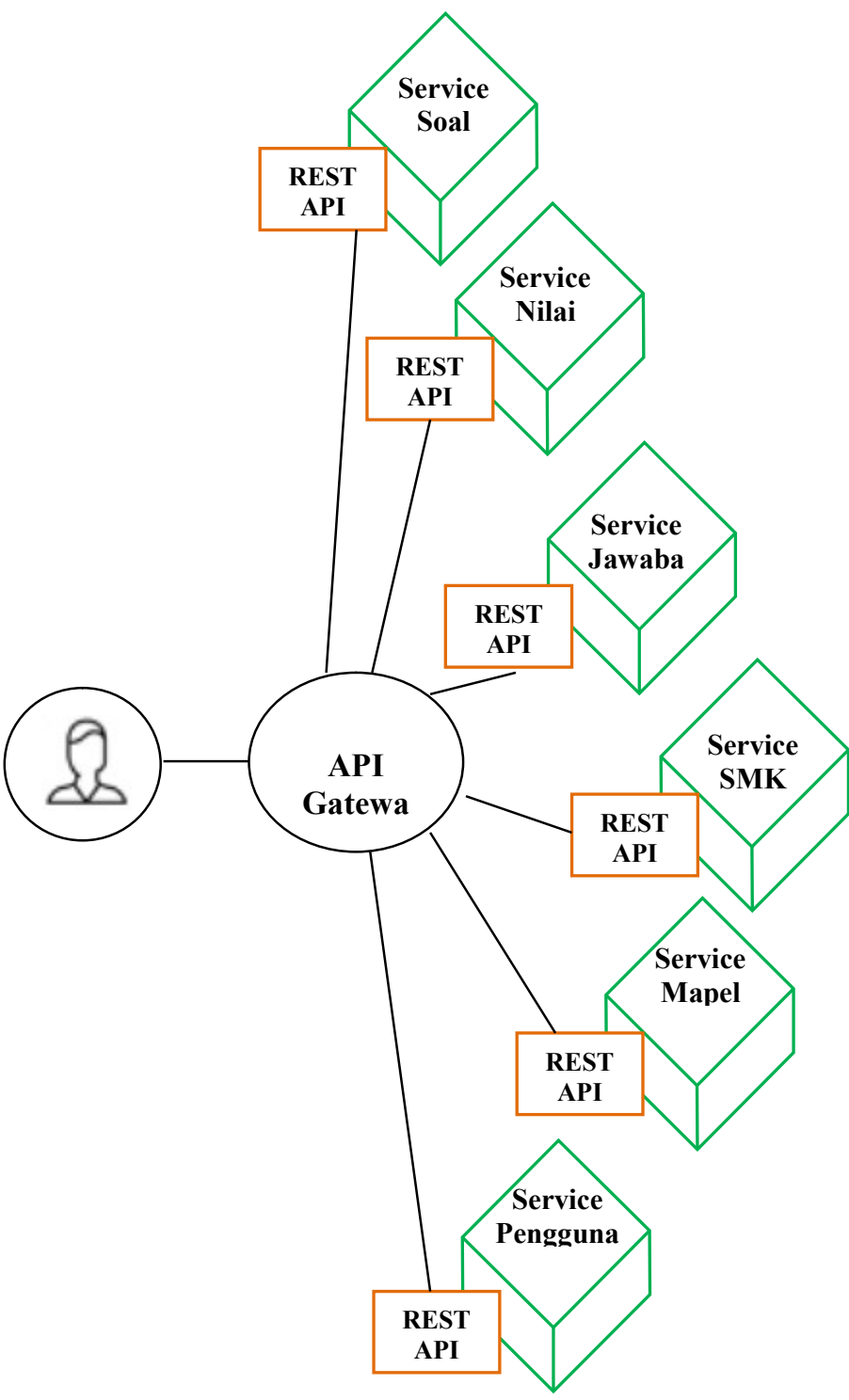

Gambar 3.Arsitektur Sistem

Seperti yang nampak pada gambar diatas, semua request dari user akan melalui API Gateway yang selanjutnya akan mengarahkan request ini ke service atau layanan tertentu. Selain itu API Gateway juga berfungsi untuk protocol translation dan menyediakan custom API yang dibutuhkan pengguna. API gateway menyediakan endpoint contohnya (/soal?soalID=101) sehingga pengguna dapat mengakses soal dengan nomor ID 101. Impementasi dari API Gateway dan sebagian mikroservice diatas dapat dilihat pada gambar berikut ini.

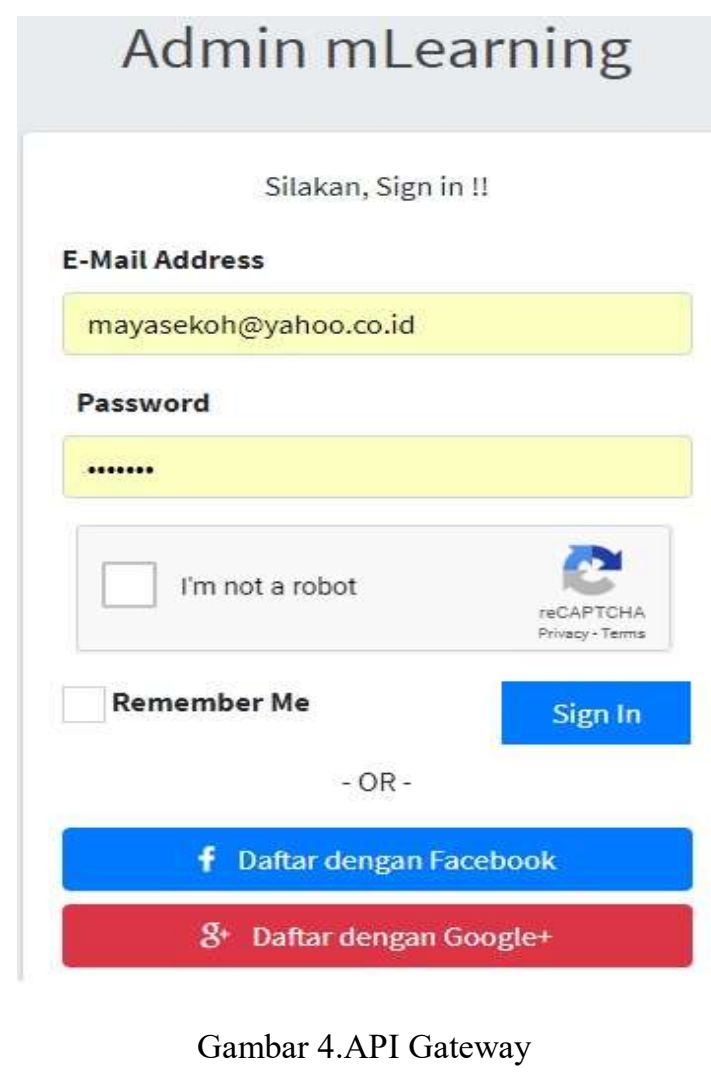

Pada gambar diatas, pengguna yang berhasil login hanya akan diberikan akses sesuai dengan instansi atau sekolahnya masing - masing. REST API memfilter pengguna dan mengarahkan ke paket data yang sesuai. Untuk keamanan proses login maka digunakan juga fitur reCAPCHA dari Google.
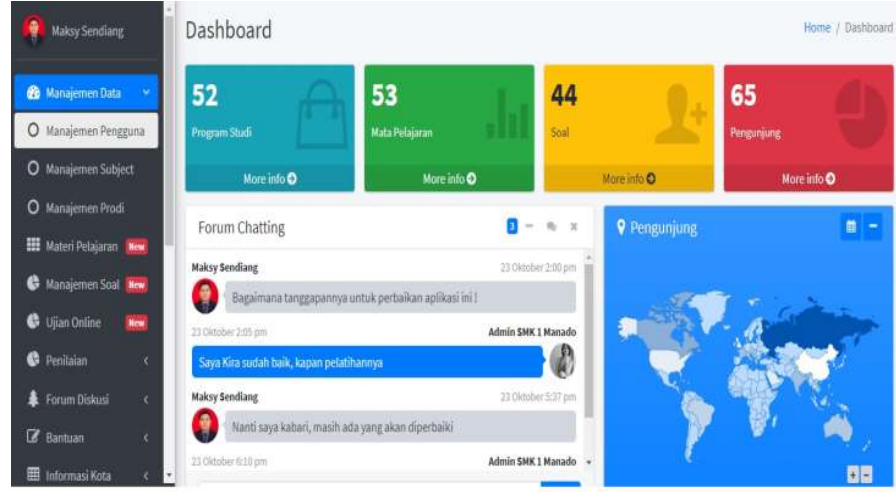

Gambar 5.Admin Service

Implementasi mikroservice dapat dilihat pada gambar dashboard utama diatas. Untuk memudahkan proses pengelolaan entity - entity yang membentuk system ini maka digunakan teknologi mikroservice. Teknologi mikroservice memecah system yang besar dengan 
mengacu pada arsitektur MVC (Model View Controller). Framework lumen dipakai untuk mengembangkan teknologi ini.

\section{Pengujian Sistem}

Pengujian sistem dalam bentuk functional testing dilakukan untuk menganalisa sistem mikroservice yang dibangun. Fungsionalitas testing adalah salah satu black box testing yang dilakukan untuk memastikan bahwa sistem berfungsi sebagaimana yang dimodelkan / diharapkan. Hasil dari fungsionalitas tersting dapat dilihat pada tabel dibawah ini.

TABEL 2

FUNGSIONALITAS TESTING

\begin{tabular}{|c|c|c|c|}
\hline No & Pengujian & Test Case & $\begin{array}{c}\text { Hasil yang } \\
\text { diharapkan }\end{array}$ \\
\hline 1 & $\begin{array}{l}\text { Fungsionalitas } \\
\text { API Gateway }\end{array}$ & $\begin{array}{l}\text { 1.User } \\
\text { memasukan } \\
\text { URL sesuai } \\
\text { REST API } \\
\text { yang } \\
\text { diinginkan } \\
\text { 2.Manipulasi } \\
\text { user terhadap } \\
\text { service yang } \\
\text { dibuka }\end{array}$ & $\begin{array}{l}\text { 1. User } \\
\text { masuk dapat } \\
\text { service yang } \\
\text { dituju } \\
\text { 2. User dapat } \\
\text { menggunakan } \\
\text { service fitur }\end{array}$ \\
\hline 2 & $\begin{array}{l}\text { Fungsionalitas } \\
\text { mikroservice } \\
\text { nilai }\end{array}$ & $\begin{array}{l}\text { 1.User membuka } \\
\text { form untuk } \\
\text { input, edit dan } \\
\text { update nilai } \\
\text { berdasarkan } \\
\text { parameter } \\
\text { tertentu } \\
\text { 2.User mengklik } \\
\text { tombol submit }\end{array}$ & $\begin{array}{l}\text { 1.Nilai dapa } \\
\text { diinput,edit, dan } \\
\text { hapus sesua } \\
\text { parameter yang } \\
\text { dipih } \\
\text { 2. Validasi data } \\
\text { benar, data bisa } \\
\text { disimpan, } \\
\text { diupdate } \\
\text { database }\end{array}$ \\
\hline 3 & $\begin{array}{l}\text { Fungsionalitas } \\
\text { mikroservice } \\
\text { soal }\end{array}$ & $\begin{array}{l}\text { 1.User membuka } \\
\text { form soal, } \\
\text { menginput,edit } \\
\text { dan hapus soal } \\
\text { sesuai } \\
\text { kebutuhan } \\
\text { 2.User mengklik } \\
\text { tombol submit }\end{array}$ & $\begin{array}{l}\text { 1. Form terbuka } \\
\text { soal dapa } \\
\text { dimanipulasi } \\
\text { sesuai kebutuhan } \\
\text { 2. Validasi berjalan } \\
\text { dan soal dapa } \\
\text { disimpan/diupdat } \\
\text { e ke database }\end{array}$ \\
\hline 4 & $\begin{array}{l}\text { Fungsionalitas } \\
\text { mikroservice } \\
\text { materi } \\
\text { pembelajaran }\end{array}$ & $\begin{array}{l}\text { 1.User membuka } \\
\text { form } \\
\text { pembelajaran } \\
\text { dan menginput } \\
\text { materi } \\
\text { pembelajaran } \\
\text { 2.User memilih } \\
\text { tombol submit }\end{array}$ & $\begin{array}{l}\text { 1. Form } \\
\text { pembelajaran } \\
\text { dapat } \\
\text { difungsikan } \\
\text { 2. Materi } \\
\text { pembelajaran } \\
\text { disimpan } \\
\text { database }\end{array}$ \\
\hline 5 & $\begin{array}{l}\text { Fungsionalitas } \\
\text { mikroservice } \\
\text { pengguna }\end{array}$ & $\begin{array}{l}\text { 1. User membuka } \\
\text { form pengguna } \\
\text { menginput, } \\
\text { edit dan hapus } \\
\text { pengguna } \\
\text { 2.User memilih } \\
\text { tombol submit }\end{array}$ & $\begin{array}{l}\text { 1. User dapat } \\
\text { menggunakan } \\
\text { form pengguna } \\
\text { dan menginput, } \\
\text { edit dan hapus } \\
\text { pengguna } \\
\text { 2.Data pengguna }\end{array}$ \\
\hline
\end{tabular}

\begin{tabular}{|c|c|c|c|}
\hline No & Pengujian & Test Case & $\begin{array}{c}\text { Hasil yang } \\
\text { diharapkan }\end{array}$ \\
\hline & & & $\begin{array}{l}\text { disimpan dalam } \\
\text { database }\end{array}$ \\
\hline
\end{tabular}

Dari table hasil pengujian diatas dapat dilihat bahwa system berjalan sesuai dengan yang diharapkan. Ini berarti bahwa system sudah dapat digunakan sesuai peruntukannya.

\section{KESIMPULAN}

Kesimpulan yang dapat diambil dari penelitian ini adalah :

1. Arsitektur mikroservice memecah aplikasi menjadi entity - entity independent yang dipanggil melalui API Gateway.

2. Aplikasi mobile learning yang dibangun memiliki enam mikroservice yang dapat dikembangkan sesuai kebutuhan dengan menambahkan service tertentu ke sistem yang telah ada.

3. Framework lumen ampuh dalam membangun mikroservice dan mendukung pengembangan RESTFUL API application

\section{UCAPAN TERIMA KASIH}

Penulis mengucapkan terima kasih kepada Direktorat Riset dan Pengabdian Masyarakat Kementerian Riset Teknologi dan Pendidikan Tinggi RI yang telah mendanai kegiatan penelitian sehingga dihasilkan luaran ini.

\section{DAFTAR PUSTAKA}

[1] Cavus,N., \& Ibrahim,D. (2009). M-Learning: An experiment in using SMS to support learning new English words. British Journal of Educational Technology, 40(1),78-91.

[2] D.V. Sanchez, E.H.Rubio, E.F.Ruiz and Viveros, "Student Role Functionalities Towards Learning Management Systems as Open Platforms Through Mobile Devices", IEEE 201 S. M. Metev and V. P. Veiko, Laser Assisted Microtechnology, 2nd ed., R. M. Osgood, Jr., Ed. Berlin, Germany: Springer-Verlag, 1998.

[3] L.Bass, P.Clements, Software Architecture in Practice, $3^{\text {rd }}$ ed, Boston, MA : Addison-Wesley professional, 2012, ch.13

[4] N.Pachler, B.Bachmair, J.Cook and G.Kress, Mobile Learning:Structures, Agency, Practices, $1^{\text {st }}$ ed,New York,NY:Springer,2010,ch. 1,pp. 3-10

[5] N.Serrano, J.Hernantes, and G.Gallado, "Mobile Web Apps", IEEE Software 2013

[6] Qiaoli Chen,Department Of engineering working software teaching and research Shaanxi Institute of technology Xi'an China, "Compare and study about owing to the three kinds important softwares develop process ", international Conference on Education Technology and Economic Management (ICETEM), 2015.

[7] Shen,R., Wang,M. (2008). Increasing interactivity in blended classrooms through a cutting-edge mobile learning system. British Journal of Educational Technology, 39(6), 1073-1086

[8] Vasiliou, A., \& Economides, A.A (2011). Mobile collaborative learning using multicast MANETs. International Journal of Mobile Communications, 5(4), 423-444. 